\title{
Gender Differences in Obesity-related Socioeconomic Costs
}

\author{
Soo Jeong Kim ${ }^{1}$, Kyoung Won $\mathrm{Cho}^{2}$, Chang Seok $\mathrm{Oh}^{3}$, Sun Mi Lee \\ 'Professor, Department of Health Administration, Division of Health Sciences, Dongseo University, Busan;' ${ }^{2}$ rofessor, Department of Health Care \\ Administration, Kosin University, Busan; ${ }^{3}$ Professor, Department of Healthcare Management, College of Health Sciences, Youngsan University, Busan; \\ ${ }^{4}$ Research Fellow, Health Insurance Research Institute, National Health Insurance Service, Wonju, Korea
}

Objectives: This study aimed to estimate the risk of disease- and death-causing obesity and to calculate direct and indirect costs using national health insurance big data. Methods: We constructed cohort data for 10,091,251 participants who underwent a national health screening between 2003 and 2004. Cox's proportional hazard models were adopted to analyze the relative risk (RR) of related diseases and causes of death, adjusted for age, smoking, alcohol consumption, and exercise. Population attributable risk (PAR) of obesity was calculated considering prevalence of obesity and RR of incidence and death of obesity related diseases. Socioeconomic costs were estimated including direct and indirect costs. Results: The risk of diabetes increased with increasing body mass index (BMI). In severely obese males, the risk of diabetes was 4.83 times higher than in normal weight males. In severely obese females, the risk of diabetes was 4.01 times higher than in normal weight females. In case of the socioeconomic cost of obesity, the direct and indirect costs differed by sex: the direct cost of male and female obesity was $50.8 \%$ and $85.9 \%$ in 2015 , respectively. Conclusions: This study identified that obesity is not only a significant risk factor of diseases and death but also the cause of economic loss for the health insurance sector. Therefore, it is considered that it is necessary to develop an intervention program to manage examinees who are determined to be obese.

Key words: Obesity, Gender, Socioeconomic costs, Diseases, Death

\section{INTRODUCTION}

Five percent of all mortalities worldwide have been attributed to obesity and overweight, indicating their global impact [1]. In most Organization for Economic Cooperation and Development (OECD) nations, roughly half the population is overweight. Due to its role as the cause of chronic disease, obesity has been receiving considerable attention in the public health sector [2]. In most OECD member countries, 1-3\% of total health expenditure is on obesity-related causes, with governments now establishing comprehensive strategies to counter the disorder [2].

Lifestyle habits, such as smoking and alcohol consumption, have been identified as major health risk factors, backed by numerous domestic and international studies with objective data on these factors' damage to health and contribution to socioeconomic loss [3-6]. Obesity is considered a

Corresponding author: Sun Mi Lee

199 Hyeoksin-ro, Wonju 26464, Korea

Tel: +82-33-736-2861, E-mail: Ism8711@nhis.or.kr

Received: March 17, 2020 Revised: May 14, 2020 Accepted: May 25, 2020

No potential conflict of interest relevant to this article was reported. risk factor in several health problems, including hypertension, hyperlipidemia, diabetes, cardiovascular disease, arthritis, and cancer [7-10]. One meta-analysis of obesity [9] found that the risk of endometrial cancer was 1.5 times higher in overweight individuals $(25 \leq$ BMI, body mass index $<30)$ and 3.2 times higher in obese individuals $(B M I \geq 30)$ compared to individuals with normal weight. Furthermore, diabetes risk was 2.4 times higher in overweight males, 6.7 times higher in overweight females, 3.9 times higher in obese males, and 12.4 times higher in obese females.

Besides affecting human health, health risk factors also cause wideranging economic loss to the public. Accounting for direct (e.g., medical costs) and indirect (e.g., premature death) costs, Jung and Ko [11] pegged the economic loss due to obesity at US \$ 1.8 billion in 2005.

Despite the implementation of health promotion programs, Korea has been unable to significantly decrease obesity prevalence; hence, requir-

How to cite this article:

Kim SJ, Cho KW, Oh CS, Lee SM. Gender differences in obesity-related socioeconomic costs. J Health Info Stat 2020;45(2):181-190. Doi: https://doi.org/10.21032/jhis.2020.45.2.181

(c) It is identical to the Creative Commons Attribution Non-Commercial License (https://creativecommons.org/licenses/by-nc/4.0) which permit sunrestricted non-commercial use, distribution, and reproduction in any medium, provided the original work is properly cited.

(c) 2020 Journal of Health Informatics and Statistics 
ing more active intervention as a social issue. Therefore, this study estimates the scale of socioeconomic loss due to obesity in order to provide data to support future legislation and policy for reducing its prevalence. We calculated the costs by sex, using the following process: first, the risks of disease and death due to obesity were calculated using large-scale, long-term cohort data constructed using health insurance big data. Second, in five alternating years, from 2005 to 2013, socioeconomic loss due to obesity was calculated after classification into direct costs (medical, transport, and nursing costs) and indirect costs (cost due to premature death and loss of productivity).

\section{METHODS}

\section{Calculation of risk and population attributable risk of disease and death}

Among all examinees who had undergone general health screening from 2003 to 2004, those who did not have weight or height measurements, duplicated examinees, and those with a history of obesity-related diseases for the past 1 year as of the date of screening were excluded and the cohort data of 10,091,251 people followed up by the end of 2015 was built up.

After adjusting for age- and health-related behaviors (alcohol consumption, smoking, or exercise), Cox's proportional hazards model was used to analyze the relative risk of related diseases and causes of death according to level of obesity (normal weight, overweight, obese, and severely obese). Information on the level of obesity was obtained from measured data acquired at the time of the national health screening. The level of obesity was categorized according to BMI (body weight in kilograms divided by the square of height in meters) into groups of normal weight $(18.5 \leq \mathrm{BMI}<23)$, overweight $(23 \leq \mathrm{BMI}<25)$, obese $(25 \leq \mathrm{BMI}<30)$, and severely obese $(30 \leq \mathrm{BMI})$ based on criteria of Korean Society for the Study of Obesity.

In order to calculate population attributable risk (PAR) in this study, we used original data from the Korea National Health and Nutrition Examination Survey and disease incidence and death of obesity related diseases from the health insurance big data for the period under study, and analyzed the annual prevalence of obesity for males and females.

On the basis of the main diseases, in the case of hospitalization, where hospitalization occurred more than once with the corresponding disease code, and in the case of outpatient cases, where outpatient treatment with the same disease code were given more than 3 times, it is defined as outbreaks of the disease.

\section{Estimation of socioeconomic cost Types of cost}

In this study, socioeconomic cost was analyzed from a social perspective. In order to ascertain long-term trends in cost, we selected five alternating years between 2007 and 2015 for analysis. The types of cost included in socioeconomic cost were categorized broadly into direct and indirect costs. Direct costs included direct medical costs, that is, the fees paid by patients for treatment while visiting medical institutions as inpatients or outpatients, or while using pharmacies. Direct non-medical costs were additional fees, which included transport costs and caring fees for inpatients. Indirect costs included future income loss from disease-related premature death and productivity loss from the inability to work due to hospital visits.

\section{Calculations}

Direct medical costs were calculated by age, sex, and disease as the total uncovered, self-funded costs. These were represented by the sum of treatment fees in the inpatient (IP), outpatient (OP), and pharmacy $(\mathrm{P})$ sectors of health insurance and medicaid, multiplied by the proportion of uncovered, self-payment in each sector $(\alpha, \beta, \gamma)$. In addition, traffic costs were calculated by multiplying the number of days with an outpatient visit $(\mathrm{OV})$ by the average transport cost for one return journey $(\mathrm{T})$ with a companion, and caring fees were calculated by multiplying the number of days as an inpatient (IV) by the average daily labor costs for caring $(\mathrm{C})$.

$$
\begin{gathered}
\mathrm{DC}=\sum_{i} \sum_{j} \sum_{k} \sum_{t}\left\{I P_{i j k}^{t} \times P A R_{i j k}(1+\alpha)+O P_{i j k}^{t} \times P A R_{i j k}(1+\beta)\right. \\
\left.+P_{i j k}^{t} \times P A R_{i j k}(1+\gamma)\right\} \\
+\sum_{i} \sum_{j} \sum_{k} \sum_{t}\left\{\left(I V_{i j k}^{t} \times P A R_{i j k} \times T^{t}\right)+\left(O V_{i j k}^{t} \times P A R_{i j k} \times T^{t}\right)\right\} \\
+\sum_{i} \sum_{j} \sum_{k} \sum_{t}\left(I V_{i j k}^{t} \times P A R_{i j k} \times C G R^{t} \times C T^{t}\right)
\end{gathered}
$$

$i=1,2, \cdots$, n disease, $j=1,2$ sex, $k=0,1, \cdots$, n age, $t=2006,2007, \cdots$ 2015

$\mathrm{PAR}_{i j k}=$ Population Attributable Risk(disease incidence) of obesity for $i$ disease, $j$ sex, and $k$ age

$\mathrm{IP}_{i j k}^{t}=$ Total medical expenses in inpatient sector of health insurance and medical aid by $i$ disease, $j$ sex, and $k$ age of $t$ year 
$\mathrm{IP}_{i j k}^{t}=$ Total medical expenses in outpatient sector of health insurance and medical aid by $i$ disease, $j$ sex, and $k$ age of $t$ year

$\mathrm{IP}_{i j k}^{t}=$ Total medical expenses in pharmacy sector of health insurance and medical aid by $i$ disease, $j$ sex, and $k$ age of $t$ year

$\alpha=$ Proportion of co-payment for coverage exclusion of total medical expenses in inpatient sector

$\beta=$ Proportion of co-payment for coverage exclusion of total medical expenses in outpatient sector

$\gamma=$ Proportion of co-payment for coverage exclusion of total medical expenses in pharmacy sector

$\mathrm{IP}_{i j k}^{t}=$ Number of hospitalized days by $i$ disease, $j$ sex, and $k$ age of $t$ year

$\mathrm{IP}_{i j k}^{t}=$ Number of visit days by $i$ disease, $j$ sex, and $k$ age of $t$ year

$\mathrm{T}^{t}=$ Average transport cost per inpatient and outpatient visit of $t$ year

$\mathrm{CGR}^{t}=$ Caregiver utilization rate of $t$ year

$\mathrm{C}^{t}=$ Daily average caring fees of $t$ year

Future income loss due to premature death (FIL) was calculated by applying the human capital approach that is most commonly used in research on the socioeconomic cost of disease. FIL was calculated by multiplying the sex-, age-, and disease-specific number of deaths (D) by the human loss per person, which, in turn, was calculated using the sex- and age-specific survival (S), employment rate (E), average yearly nominal wage $(Y W)$, the rate of increase in nominal wage $(\varepsilon)$, and the nominal interest rate (r) for every year from the year after death up to the average lifespan.

$\mathrm{FIL}=\sum_{i} \sum_{j} \sum_{k} \sum_{t} D_{i j k}^{t} \times P A R_{i j k}$

$\times\left(\begin{array}{c}{\left[S_{j k+1}^{t} \times E_{j k+1}^{t} \times \frac{Y W_{j k+1}^{t}\left(1+\varepsilon_{t+1}\right)}{\left(1+\gamma_{t+1}\right)}\right]+\left[S_{j k+2}^{t} \times E_{j k+2}^{t} \times \frac{Y W_{j k+2}^{t}\left(1+\varepsilon_{t+1}\right)\left(1+\varepsilon_{t+2}\right)}{\left(1+\gamma_{t+1}\right)\left(1+\varepsilon_{t+2}\right)}\right]+\cdots} \\ +\left[S_{j k+n}^{t} \times E_{j k+n}^{t} \times \frac{Y W_{j k+n}^{t}\left(1+\varepsilon_{t+1}\right)\left(1+\varepsilon_{t+2}\right)\left(1+\varepsilon_{t+n}\right)}{\left(1+\gamma_{t+1}\right)\left(1+\varepsilon_{t+2}\right) \cdots\left(1+\varepsilon_{t+n}\right)}\right]\end{array}\right\}$

$i=1,2, \cdots, \mathrm{n}$ disease, $j=1,2 \operatorname{sex}, k=0,1, \cdots, \mathrm{n}$ age, $t=2006,2007, \cdots$, 2015

$\mathrm{D}_{i j k}^{t}=$ Number of death by $i$ disease, $j$ sex, and $k$ age of $t$ year

$\mathrm{PAR}_{i j k}=$ Population Attributable Risk(death) of obesity for $i$ disease, $j$ sex, and $k$ age

$\mathrm{S}_{j k+n}^{t}=$ Survival probability of time $(\mathrm{k}+\mathrm{n})$ of person who has $i$ disease, $j$ sex, and $k$ age of $t$ year

$\mathrm{E}_{j k+n}^{t}=$ Employment rate of time $(\mathrm{k}+\mathrm{n})$ of person who has $i$ disease, $j$ sex, and $k$ age of $t$ year
$\mathrm{YW}_{j k+n}^{t}=$ Annual average wage of time $(\mathrm{k}+\mathrm{n})$ of person who has $i$ disease, $j$ sex, and $k$ age of $t$ year

$\varepsilon=$ Nominal wage increasing rate

$\gamma=$ Nominal interest rate

Productivity loss (PL) from loss of work due to hospital visits was calculated as the product of sex- and age-specific average daily nominal wage (DW) and employment (E) with sex-, age-, and disease-specific number of days as an inpatient (IV) and one-third the number of days visiting as an outpatient (OV). In order to adjust for the difference in PL for inpatient and outpatient visits, the number of non-productive days was calculated by adding the number of days as an inpatient to onethird of the number of days as an outpatient.

$$
\mathrm{PL}=\sum_{i} \sum_{j} \sum_{k} \sum_{t}\left\{\left(I V_{i j k}^{t}+\frac{1}{3} O V_{i j k}^{t}\right) \times P A R_{i j k} \times E_{j k}^{t} \times D W_{j k}^{t}\right\}
$$

$i=1,2, \cdots, \mathrm{n}$ disease, $j=1,2 \operatorname{sex}, k=0,1, \cdots, \mathrm{n}$ age, $t=2006,2007, \cdots$, 2015

$\mathrm{IV}_{i j k}^{t}=$ Number of hospitalized days by $i$ disease, $j$ sex, and $k$ age of $t$ year

$\mathrm{OV}^{t}{ }_{i j k}=$ Number of visit days by $i$ disease, $j$ sex, and $k$ age of $t$ year

$\mathrm{PAR}_{i j k}=$ Population Attributable Risk (disease incidence) of obesity for $i$ disease, $j$ sex, and $k$ age

$\mathrm{PAR}_{i j k}=$ Employment rate of $j$ sex and $k$ age of $t$ year

$\mathrm{DW}_{j k}^{t}=$ Daily average wage of $j$ sex and $k$ age of $t$ year

\section{RESULTS}

\section{Disease risk}

A group of 36 obesity-related diseases were constructed by reviewing previous studies. Of these, analysis of general health screening data from the national health insurance demonstrated that 29 diseases in male subjects and 33 diseases in female subjects were associated with obesity. Although there may be small differences in each disease group, the risk of disease generally increased with increasing obesity, and was slightly higher in female subjects than male subjects (Table 1).

In obese males, the highest relative risk was measured to be 2.52 times the risk for normal weight males for diabetes, followed by hypertension, metabolic disorders, congestive heart failure, ischemic heart disease, and renal cancer. In severely obese males, the highest relative risk was mea- 
Table 1. Relative risk* on obesity-related diseases of obesity status by gender

\begin{tabular}{|c|c|c|c|c|c|c|}
\hline \multirow{2}{*}{ Diseases } & \multicolumn{3}{|c|}{ Men } & \multicolumn{3}{|c|}{ Women } \\
\hline & Overweight & Obesity & Severe obesity & Overweight & Obesity & Severe obesity \\
\hline Esophageal cancer & - & - & - & 1.17 & - & - \\
\hline Gastric adenocarcinoma & - & 1.04 & - & 1.09 & 1.16 & 1.14 \\
\hline Colorectal cancer & 1.14 & 1.21 & 1.10 & 1.18 & 1.25 & 1.16 \\
\hline Liver cancer & 1.04 & 1.10 & 1.36 & 1.12 & 1.19 & 1.23 \\
\hline Gallbladder cancer & 1.16 & 1.28 & 1.64 & 1.22 & 1.34 & 1.60 \\
\hline Pancreatic cancer & - & 1.15 & 1.28 & 1.12 & 1.29 & 1.45 \\
\hline Skin cancer & - & 1.14 & - & 1.26 & 1.34 & - \\
\hline Breast cancer & - & - & - & 1.08 & 1.20 & 1.28 \\
\hline Uterine cervix cancer & - & - & - & 1.13 & 1.23 & - \\
\hline Endometrial cancer & - & - & - & 1.24 & 1.44 & 2.49 \\
\hline Ovarian cancer & - & - & - & - & 1.22 & - \\
\hline Prostate cancer & 1.21 & 1.21 & 1.19 & - & - & - \\
\hline Renal cell carcinoma & 1.40 & 1.64 & 1.99 & 1.41 & 1.74 & 1.79 \\
\hline Ureteral cancer & - & 1.20 & - & - & 1.27 & - \\
\hline Bladder cancer & 1.17 & 1.24 & - & - & - & - \\
\hline Brain cancer & - & - & - & - & 1.39 & - \\
\hline Thyroid cancer & 1.26 & 1.48 & 1.70 & 1.25 & 1.33 & 1.18 \\
\hline Hodgkin lymphoma & - & 1.47 & 2.46 & - & - & - \\
\hline Non-Hodgkin lymphomas & 1.20 & 1.20 & - & 1.25 & 1.28 & 1.35 \\
\hline Multiple myeloma & 1.20 & 1.37 & - & 1.27 & 1.23 & - \\
\hline Leukemia & - & 1.12 & - & 1.30 & 1.29 & - \\
\hline Diabetes mellitus & 1.64 & 2.52 & 4.83 & 1.87 & 2.64 & 4.01 \\
\hline Metabolic disorder & 1.45 & 1.73 & 2.03 & 1.48 & 1.76 & 1.93 \\
\hline Cataract & 1.20 & 1.28 & 1.29 & 1.26 & 1.40 & 1.37 \\
\hline Hypertension & 1.47 & 1.99 & 2.95 & 1.48 & 1.96 & 2.69 \\
\hline Ischemic heart diseases & 1.36 & 1.66 & 1.99 & 1.42 & 1.70 & 2.03 \\
\hline Pulmonary thromboembolism & 1.21 & 1.33 & 1.78 & 1.17 & 1.72 & 2.85 \\
\hline Congestive heart failure & 1.30 & 1.67 & 3.07 & 1.31 & 1.79 & 2.76 \\
\hline Cerebral hemorrhage & 1.04 & 1.25 & 1.75 & 1.13 & 1.25 & 1.41 \\
\hline Ischemic stroke & 1.30 & 1.51 & 1.74 & 1.30 & 1.51 & 1.69 \\
\hline Other cerebrovascular diseases & 1.24 & 1.43 & 1.67 & 1.26 & 1.45 & 1.54 \\
\hline Asthma & - & 1.03 & - & 1.18 & 1.35 & 1.49 \\
\hline Gallbladder disease & 1.18 & 1.34 & 1.52 & 1.19 & 1.38 & 1.50 \\
\hline Arthrosis & 1.14 & 1.26 & 1.41 & 1.32 & 1.63 & 1.85 \\
\hline Dorsopathy & 1.06 & 1.08 & 1.04 & 1.16 & 1.28 & 1.26 \\
\hline Toxemia & - & - & - & 1.55 & 2.33 & 3.43 \\
\hline
\end{tabular}

${ }^{*}$ All of relative risk was statically significant $(p<0.05)$.

sured to be 4.83 times the risk for normal weight males for diabetes, followed by congestive heart failure, hypertension, Hodgkin's lymphoma, metabolic disorders, ischemic heart disease, and renal cancer. In overweight females, the highest relative risk was measured to be 1.87 times the risk for normal weight females for diabetes, followed by toxemia, metabolic disorders, hypertension, ischemic heart disease, renal cancer, arthropathy, and congestive heart failure. In obese females, the highest relative risk was measured to be 2.64 times the risk for normal weight fe- males for diabetes, followed in order by toxemia, hypertension, congestive heart failure, metabolic disorders, renal cancer, pulmonary embolism, ischemic heart disease, arthropathy, and ischemic stroke.

Similarly, in severely obese females, the highest relative risk was measured to be 4.01 times the risk for normal weight females for diabetes, followed by toxemia, pulmonary embolism, congestive heart failure, hypertension, endometrial cancer, ischemic heart disease, metabolic disorders, arthropathy, renal cancer, ischemic stroke, gallbladder cancer, and 
Table 2. Relative risk* on obesity-related deaths of obesity status by gender

\begin{tabular}{|c|c|c|c|c|c|c|}
\hline \multirow{2}{*}{ Diseases } & \multicolumn{3}{|c|}{ Men } & \multicolumn{3}{|c|}{ Women } \\
\hline & Overweight & Obesity & Severe obesity & Overweight & Obesity & Severe obesity \\
\hline Colorectal cancer & 1.10 & 1.23 & 1.31 & 1.15 & 1.17 & 1.32 \\
\hline Liver cancer & - & 1.08 & 1.61 & 1.12 & 1.27 & 1.75 \\
\hline Gallbladder cancer & 1.16 & 1.19 & 2.27 & 1.37 & 1.55 & 1.71 \\
\hline Pancreatic cancer & 1.09 & 1.16 & 1.34 & 1.15 & 1.32 & 1.44 \\
\hline Skin cancer & - & - & 4.14 & - & 1.96 & 3.14 \\
\hline Breast cancer & - & - & - & 1.21 & 1.42 & 2.26 \\
\hline Uterine cervical cancer & - & - & - & - & - & 1.64 \\
\hline Endometrial cancer & - & - & - & - & 1.49 & 2.56 \\
\hline Ovarian cancer & - & - & - & 1.25 & 1.24 & 1.36 \\
\hline Prostate cancer & 1.15 & 1.24 & 1.71 & - & - & - \\
\hline Renal cancer & 1.29 & 1.50 & 2.10 & 1.40 & 1.52 & 1.98 \\
\hline Ureteral cancer & - & - & - & - & 1.84 & 2.01 \\
\hline Bladder cancer & - & 1.18 & - & - & - & - \\
\hline Brain cancer & - & - & - & - & 1.29 & 1.69 \\
\hline Thyroid cancer & 1.43 & 1.32 & 3.16 & 1.84 & 2.10 & 2.79 \\
\hline Hodgkin lymphomas & - & - & - & - & 1.20 & - \\
\hline Non-Hodgkin lymphomas & - & 1.10 & 2.24 & 1.16 & 1.35 & 1.73 \\
\hline Multiple myeloma & 1.27 & 1.24 & - & 1.28 & 1.35 & 1.48 \\
\hline Leukemia & - & - & 1.36 & 1.27 & 1.19 & 1.57 \\
\hline Diabetes & 1.14 & 1.20 & 1.89 & 1.34 & 1.80 & 2.73 \\
\hline Metabolic disorder & - & 5.41 & 27.08 & - & - & - \\
\hline Hypertension & 1.16 & 1.52 & 1.82 & - & 1.11 & 1.72 \\
\hline Ischemic heart diseases & 1.20 & 1.38 & 1.62 & 1.21 & 1.36 & 1.81 \\
\hline Pulmonary thromboembolism & - & - & 2.36 & - & 1.44 & 2.75 \\
\hline Cerebral hemorrhage & - & - & 1.89 & - & - & 1.28 \\
\hline Ischemic stroke & 1.09 & 1.15 & 1.86 & 1.14 & 1.28 & 1.64 \\
\hline Other cerebrovascular diseases & 1.13 & 1.39 & 1.19 & - & 1.18 & 1.28 \\
\hline Gallbladder disease & - & - & - & - & 1.49 & 2.25 \\
\hline Arthrosis & - & - & - & - & 2.43 & 2.61 \\
\hline Dorsopathy & - & - & 2.24 & - & - & 2.26 \\
\hline
\end{tabular}

${ }^{*}$ All of relative risk was statically significant $(p<0.05)$.

other cerebrovascular diseases (Table 2).

\section{Risk of death}

Of the 36 disease groups that were analyzed for disease risk, the risk of death due to obesity was analyzed in 30 diseases, excluding the six diseases with no cases of death. Unlike disease risk, there were sex differences in diseases with a high risk of death. In overweight males, the highest relative risk of death was 1.43 times the risk for normal weight males for thyroid cancer, followed by renal cancer, multiple myeloma, and ischemic heart disease. For obese males, the highest relative risk of death was 5.41 times the risk for normal weight males for metabolic disorders, followed by hypertension, renal cancer, other cerebrovascular disease, ischemic heart disease, thyroid cancer, multiple myeloma, pros- tate cancer, and colorectal cancer. For severely obese males, the highest relative risk of death was 27.08 times the risk for normal weight males for metabolic disorders, followed by skin cancer, thyroid cancer, pulmonary embolism, gallbladder cancer, non-Hodgkin's lymphoma, dorsopathy, and renal cancer. For overweight females, the highest relative risk of death was 1.84 times the risk for normal weight females for thyroid cancer, followed by renal cancer, gallbladder cancer, diabetes, multiple myeloma, leukemia. For obese females, the highest relative risk of death was 2.43 times the risk for normal weight females for arthropathy, followed by thyroid cancer, Hodgkin's lymphoma, skin cancer, ureteral cancer, diabetes, gallbladder cancer, renal cancer. Finally, for severely obese females, the highest relative risk of death was 3.14 times the risk for normal weight females for skin cancer, followed by thyroid cancer, pulmo- 
Table 3. Estimation of socioeconomic costs by gender

\begin{tabular}{|c|c|c|c|c|c|c|c|c|c|c|}
\hline & \multicolumn{2}{|l|}{2007} & \multicolumn{2}{|l|}{2009} & \multicolumn{2}{|l|}{2011} & \multicolumn{2}{|l|}{2013} & \multicolumn{2}{|l|}{2015} \\
\hline & Costs & $\%$ & Costs & $\%$ & Costs & $\%$ & Costs & $\%$ & Costs & $\%$ \\
\hline \multicolumn{11}{|l|}{ Men } \\
\hline \multicolumn{11}{|l|}{ Direct non-medical costs } \\
\hline Transportation & $47,531,458$ & 1.6 & $58,006,273$ & 1.7 & $53,348,678$ & 1.5 & $82,060,755$ & 2.0 & $99,914,849$ & 2.0 \\
\hline Caring & $84,279,863$ & 2.9 & $105,022,949$ & 3.1 & $108,534,891$ & 3.0 & $144,157,161$ & 3.4 & $170,672,026$ & 3.5 \\
\hline Premature death & $1,250,374,277$ & 43.2 & $1,216,413,964$ & 36.3 & $1,164,066,655$ & 32.5 & $1,317,444,851$ & 31.4 & $1,412,466,451$ & 28.9 \\
\hline Productivity loss & $540,152,529$ & 18.7 & $660,737,532$ & 19.7 & $737,252,651$ & 20.6 & $881,481,809$ & 21.0 & $988,797,310$ & 20.3 \\
\hline Subtotal of indirect costs & $1,790,526,805$ & 61.9 & $1,877,151,497$ & 56.0 & $1,901,319,306$ & 53.1 & $2,198,926,660$ & 52.4 & $2,401,263,761$ & 49.2 \\
\hline Total & $2,894,663,201$ & 100.0 & $3,349,388,812$ & 100.0 & $3,582,701,555$ & 100.0 & $4,198,331,378$ & 100.0 & $4,881,984,082$ & 100.0 \\
\hline \multicolumn{11}{|l|}{ Women } \\
\hline Subtotal of direct costs & $1,921,795,780$ & 79.7 & $2,320,559,818$ & 82.7 & $2,731,896,158$ & 83.7 & $3,195,006,513$ & 84.4 & $3,667,367,612$ & 85.9 \\
\hline Premature death & $236,666,253$ & 9.8 & $217,714,811$ & 7.8 & $214,100,441$ & 6.6 & $224,624,863$ & 5.9 & $224,659,657$ & 5.3 \\
\hline Productivity loss & $253,666,253$ & 10.5 & $268,283,069$ & 9.6 & $317,432,499$ & 9.7 & $366,438,189$ & 9.7 & $376,565,014$ & 8.8 \\
\hline Subtotal of indirect costs & $489,755,233$ & 20.3 & $485,997,880$ & 17.3 & $531,532,940$ & 16.3 & $591,063,052$ & 15.6 & $601,224,670$ & 14.1 \\
\hline Total & $2,411,551,013$ & 100.0 & $2,806,557,698$ & 100.0 & $3,263,429,098$ & 100.0 & $3,786,069,564$ & 100.0 & $4,268,592,283$ & 100.0 \\
\hline \multicolumn{11}{|l|}{ All } \\
\hline Direct medical costs & $2,653,769,928$ & 50.0 & $3,342,924,062$ & 54.3 & $3,944,113,510$ & 57.6 & $4,539,178,809$ & 56.9 & $5,381,228,321$ & 58.8 \\
\hline \multicolumn{11}{|c|}{ Direct non-medical costs } \\
\hline Transportation & $138,471,826$ & 2.6 & $161,189,828$ & 2.6 & $155,586,591$ & 2.3 & $237,146,853$ & 3.0 & $280,430,526$ & 3.1 \\
\hline Caring & $233,690,421$ & 4.4 & $288,683,244$ & 4.7 & $313,578,305$ & 4.6 & $418,085,569$ & 5.2 & $486,429,086$ & 5.3 \\
\hline
\end{tabular}

Unit: 1,000 won.

nary embolism, diabetes, arthrosis, dorsopathy, endometrial cancer, and breast cancer (Table 3).

\section{Socioeconomic cost by gender}

The socioeconomic cost of obesity in 2015 was 9.150 trillion (where \# is the Korean won), which represents around 2 times increase compared to 5.306 trillion in 2007. By sex, the cost of male obesity in 2015 was 4.881 trillion (53.4\%) and the cost of female obesity was 4.268 trillion (46.6\%). As per annual trends, the cost for males in 2015 ( 4.881 trillion) increased 1.7 times compared to 2.894 trillion in 2007. For females, the cost in 2015 (4.268 trillion KRW) increased by 1.8 times compared to 2.411 trillion in 2007. By cost type, in 2015, direct costs were 6.148 trillion $(67.2 \%)$ and indirect costs were 3.002 trillion
(32.8\%). Specifically, direct medical costs were 5.381 trillion (58.8\%), productivity loss due to use of medical services was 1.365 trillion (14.9\%), future income loss due to premature death was 1.637 trillion (17.9\%), caring fees were 486 billion (5.3\%), and transport costs were \# 280 billion (3.1\%).

With regard to increase in obesity-related costs caring fees increased by 2.08 times - the largest increase - followed by direct medical costs by 2.03 times, transport costs by 2.03 times, and future income loss due to premature death by 1.72 times the cost in 2015, comparing to 2007 .

\section{DISCUSION}

This study is important insofar as we estimated the economic cost of 
obesity to the public, and identified differences in the cost between males and females.

In previous studies on the association between colorectal cancer and obesity, obesity reportedly showed a significant association with the risk of developing and dying from colorectal cancer, with an increased risk for males [7,12-14].

A meta-analysis by Guh et al. [9] showed that the risk of colorectal cancer was 1.5 times higher in overweight males and females combined, 2 times higher in obese males, and 1.7 times higher in obese females. In a study by Moghaddam et al. [12], the risk of colorectal cancer in individuals with a BMI of 30 or higher was 1.2 times higher compared to individuals with a BMI of less than 25 , and by sex, the risk was 1.4 times higher in males and 1.1 times higher in females. Dai et al. [13] reported that the risk of colorectal cancer in individuals with a BMI of at least 25 was 1.4 times higher for males and 1.1 times higher for females compared to individuals with a BMI of 18.5-24.9.

Jee et al. [14] analyzed obesity and the risk of cancer in a 14-year prospective cohort study in 1,213,829 Korean subjects aged 30-95 years who had undergone a health screening in 1992-1995. When they analyzed ageadjusted odds ratios, the risk of colorectal cancer in obese (BMI $\geq 30)$ males was 1.4 times higher compared to individuals with a BMI of 2324.9, but there was no difference for females. Meanwhile, the risk of rectal cancer was 1.2 times higher in obese males and 1.1 times higher in obese females.

The diseases that showed a high risk in both males and females were, in order, diabetes, congestive heart failure, and hypertension. In a study by Guh et al. [9], the risk of congestive heart failure was lower than in the present study, and this risk was higher in males than females. The authors reported that the risk of diabetes was 3.9 times higher in males with a BMI of 30 or more, but was 12.4 times higher in females. These results are similar to our study for males, but differ for females. Several meta-analyses on cancer risks have confirmed that BMI correlates with an increased risk of colorectal cancer, colon cancer, rectal cancer, breast cancer, uterine cancer, cervical cancer, ovarian cancer, pancreatic cancer, liver cancer, gallbladder cancer, renal cancer, bladder cancer, lung cancer, esophageal cancer, gastric cancer, skin cancer, and multiple myeloma. The present study also showed similar results. No cancers showed any clear difference in risk between males and females.

The items included in this study's estimation of cost were broadly categorized into direct costs, indirect costs, and other costs. Direct costs in- clude direct medical costs, which are treatment fees paid while using inpatient and outpatient services at a medical institution, or while using pharmacies. Direct non-medical costs are additional expenses incurred when using medical institutions for treatment, such as nursing fees.

Indirect costs include future income loss due to disease-related premature death, productivity loss due to loss of work when visiting medical institutions for treatment, and, in the case of subjects who drink, reduced productivity at work due to excessive alcohol consumption.

On analyzing direct costs - including medical costs, transport costs, and nursing fees - and indirect costs - including the cost of premature death and productivity - Jung and Ko [11] found that the cost of obesity was $\$ 2.555$ trillion in 2005 . This figure is lower than the total cost for 2013 in our study, which was 3.431 trillion, because, unlike Jung and Ko [11], we included pharmacy treatment fees from health insurance data, treatment fees paid by motor insurance, and loss of assets and administrative costs due to health risk factors. In addition, this likely reflects differences in the population attributable risk applied when estimating cost and the range of health risk factor-related diseases.

In previous domestic studies, the socioeconomic cost of obesity has been estimated at 1.8715 trillion in 2003 [15] and 2.555 trillion in 2005 [11], but this differs slightly from the estimate of 3.431 trillion for 2005 in our study. Notably, these previous studies used BMI $\geq 25$ as the criterion for obesity, while our study used a criterion of BMI $\geq 23$ to include overweight, and this can be assumed to be the reason for the higher cost estimate.

A Swiss report published in 2009 [16] estimated the socioeconomic cost of obesity in Switzerland for 2006, defining obesity as BMI $\geq 25$. Direct costs included medication, nutritional consultation, and surgical treatment for obesity, while indirect costs included comorbidities. The cost of obesity in Switzerland was reported to be CHF 3.9 billion (where CHF is the Swiss franc; Confoederation Helvetica) (67.0\%) in direct costs, and CHF 1.9 billion (33.0\%) in indirect costs. Thus, direct costs were approximately 2 times higher than indirect costs.

When Pitayatienanan et al. (2014) estimated the socioeconomic cost of obesity in Thailand, they calculated direct costs using only treatment fees, and indirect costs using productivity loss and cost of premature death. Treatment fees for direct costs included inpatient treatment fees and outpatient treatment fees, and, indirect costs included productivity loss due to premature death and productivity loss from loss of work due to hospital visits. The socioeconomic cost of obesity in Thailand in 2009 
was $B 12.1$ billion (where $B$ is the Thai baht). The cost of premature death was the highest, at $\mathbb{B} 5.9$ billion (48.3\%), followed by treatment fees at B 5.6 billion (46.0\%), and productivity loss at B 700 million (5.7\%) in Thailand [6].

In 2008, the socioeconomic cost of obesity in Germany was found to be $€ 16.8$ billion. Of the $€ 9.9$ billion in 2002 , direct costs were $€ 4.9$ billion (49.2\%) and indirect costs were $€ 5$ billion (51.5\%). In 2008,direct costs were $€ 8.6$ billion (50.8\%) and indirect costs were $€ 8.2$ billion (48.5\%), making direct costs relatively higher. Over time, the direct costs have become marginally higher than the indirect costs; however, there is no considerable difference.

Our study showed a cost share of $67.2 \%$ for direct costs and $32.8 \%$ for indirect costs in 2015 , compared to $57.0 \%$ for direct costs and $43.0 \%$ for indirect costs in 2007. Hence, in eight years, direct costs have increased considerably relative to indirect costs. Furthermore, we examined the difference between direct and indirect costs by sex. In 2015, the socioeconomic cost of male obesity was $50.8 \%$ for direct costs and $49.2 \%$ for indirect costs; for female obesity, it was $85.9 \%$ for direct costs and $14.1 \%$ for indirect costs. Thus, the proportion of direct costs was almost twice as high for females compared to males, and the proportion of indirect costs was more than twice as high for males compared to females. With employment rates, the rate of participation in economic activity over the last 10 years was reported to be $74 \%$ for males and $50 \%$ for females [18]. This is thought to have had a major impact on the sex differences in indirect costs, which include loss of productivity.

In the study of Jeong et al. [18], the socio-economic cost of obesity was found to be higher for men than women for both direct and indirect costs when BMI 23 was set as the basis for obesity. The combined socioeconomic cost of the total obesity was higher in men than in women in the overall BMI. As a result of this study, the direct cost of obesity was higher in women in 2015, as 2.48 trillion won for men and 3.66 trillion won for women and the indirect cost was higher in men as 601.2 billion won for women and 2.42 trillion won for men. At the total cost, men were 4.88 trillion won, more than women of 4.26 trillion won. This result is consistent with that of Jeong's previous study. In other words, it can be predicted that men spend more costs than women on production loss and income loss costs, which is related to the higher participation of men in the current social productivity.

For another reason, PAR, one of the basic indicators in estimating the socio-economic cost of obesity, is determined by disease outbreak or mortality risk and obesity rate. In the case of obesity rate, there were differences between genders according to age groups, but there was no significant difference due to the offset effect when divided into men and women. On the other hand, in the case of disease outbreaks and mortality risks, due to the limitation of population size, it was difficult to analyze by age group, so it was analyzed by gender only. As a result, the relationship between disease and cause of death and obesity was higher in women than in men. Therefore, the gender differences in obesity costs in this study are believed to be due to differences in disease incidence and mortality risk.

This study is strengthened by the fact that we constructed and analyzed a cohort by linking national health screening data with health insurance. Nevertheless, there are still several limitations in the study data and methods of analysis.

First, there are additional costs that could be incurred by health risk factors, such as the cost of purchasing health foods and medical devices; assisting devices for prevention, treatment, and management of disease; the time cost of using medical institutions and pharmacies; and the cost of reduced quality of life for the patient and their family. However, because it was difficult to acquire the basic data needed to calculate these costs objectively, they were excluded from the scope of the study in order to ensure validity. This limitation may result in a marginal underestimation of the total cost.

Second, when using health insurance data for medical, transport, and nursing fees and other productivity loss from use of medical services, data is extracted and classified according to the main complaint recorded on the health insurance claims data. Thus, it is possible that accompanying diseases, other than the main complaint, could have affected the results.

Third, productivity loss due to use of medical services was calculated as the loss of wages due to disease-related absence from work. Therefore, this study included any reduction or loss of income due to the patient visiting a medical institution - as an inpatient or outpatient - for treatment of a disease resulting from health risk factors. However, depending on the severity of the disease, there could be cases of individuals taking sick leave to rest at home, but there are no data that allow this population to be classified. Therefore, the loss of productivity for this population was not included in our study, thus underestimating this loss due to medical use.

Fourth, this study failed to estimate the various cost items that caused 
obesity by including only the cost that can be estimated quantitatively through consideration of the methodology of the previous study.

In this study, we confirmed that obesity causes significant economic loss not only for the health insurance sector, but also for the entire society. Hence, it is important to determine the extent of change in health risk factors for individuals using health screening data, which can show the health behaviors of insurance subscribers. Furthermore, we must review plans to improve focused follow-up management.

\section{ORCID}

$\begin{array}{ll}\text { Soo Jeong Kim } & \text { https://orcid.org/0000-0002-2453-5945 } \\ \text { Kyoung Won Cho } & \text { https://orcid.org/0000-0002-6396-2747 } \\ \text { Chang Seok Oh } & \text { https://orcid.org/0000-0002-5314-5612 } \\ \text { Sun Mi Lee } & \text { https://orcid.org/0000-0003-3051-2798 }\end{array}$

\section{REFERENCES}

1. World Health Organization. Global health risks: mortality and burden of disease attributable to selected major risks. Geneva: World Health Organization; 2009.

2. Sassi F. Obesity and the economics of prevention: fit not fat. Paris: Organization for Economic Co-operation and Development; 2010.

3. Bolin K, Lindgren B. Smoking, healthcare cost, and loss of productivity in Sweden 2001. Scand J Public Health 2007;35(2):187-196. DOI: $10.1080 / 14034940600858557$

4. Collins DJ, Lapsley HM. The costs of tobacco, alcohol and illicit drug abuse to Australian society in 2004/05. : Department of Health and Aging Canberra; 2008.

5. Kang JH, Jeong BG, Cho YG, Song HR, Kim KA. Socioeconomic costs of overweight and obesity in Korean adults. J Korean Med Sci 2011; 26(12):1533-1540.

6. Pitayatienanan P, Butchon R, Yothasamut J, Aekplakorn W, Teerawattananon Y, Suksomboon N, et al. Economic costs of obesity in Thailand: a retrospective cost-of-illness study. BMC Health Ser Res 2014;14:146. DOI: 10.1186/1472-6963-14-146

7. Parr CL, Batty GD, Lam TH, Barzi F, Fang X, Ho SC, et al. Body-mass index and cancer mortality in the Asia-Pacific Cohort Studies Collaboration: pooled analyses of 424519 participants. Lancet Oncol 2010; 11(8):741-752. DOI: 10.1016/S1470-2045(10)70141-8

8. Zhou BF. Effect of body mass index on all-cause mortality and incidence of cardiovascular diseases--report for meta-analysis of prospective studies open optimal cut-off points of body mass index in Chinese adults. Biomed Environ Sci 2002;15(3):245-252.

9. Guh DP, Zhang W, Bansback N, Amarsi Z, Birmingham CL, Anis AH. The incidence of co-morbidities related to obesity and overweight: a systematic review and meta-analysis. BMC Public Health 2009;9:88. DOI: $10.1186 / 1471-2458-9-88$

10. Poudel RD, Karmacharya P. Obesity and outcomes in rheumatoid arthritis. Semin Arthritis Rheum 2017; 47(1):e2. DOI: 10.1016/j.semarthrit.2017.03.016

11. Jung Y, Ko S, Lim H. The socioeconomic cost of adolescent obesity. Health Soc Welf Rev 2010;30:195-219 (Korean).

12. Moghaddam AA, Woodward M, Huxley R. Obesity and risk of colorectal cancer: a meta-analysis of 31 studies with 70,000 events. Cancer Epidemiol Biomarkers Prev 2007;16(12):2533-2547. DOI: 10.1158/10559965.EPI-07-0708

13. Dai Z, Xu Y, Niu L. Obesity and colorectal cancer risk: a meta-analysis of cohort studies. World J Gastroenterol 2007;13(31):4199-4206. DOI: 10.3748/wjg.v13.i31.4199

14. Jee SH, Yun JE, Park EJ, Cho ER, Park IS, Sull JW, et al. Body mass index and cancer risk in Korean men and women. Int J Cancer 2008; 123(8):1892-1896. DOI: 10.1002/ijc.23719

15. Ahn BC, Joung H. Socioeconomic cost of obesity in Korea. Korean J Nutr 2005;38(9):786-792 (Korean).

16. Schneider H, Venetz W, Berardo CG. Overweight and obesity in Switzerland-Part 1: Cost burden of adult obesity in 2007. Basel, Switzerland: Bundesamtfür Gesundheit (BAG); 2009.

17. Korea Statistical Information Service. Available at: http://kosis.kr/statisticsList/statisticsList_01List.jsp? vwcd=MT_ZTITLE\&parmTabId=M_ 01_01\#SubCont [accessed on May 2, 2020].

18. Jeong BG, Moon OR, Kim NS, Kang JH, Yoon TH, Lee SY, et al. Socioeconomic costs of obesity for Korean adults. Korean J Prev Med 2002;35(1):1-12 (Korean). 


\section{국문초록}

\section{비만관련 사회경제적 비용의 성별 차이}

김수정'·조경원 $\cdot$ 오창석 3 이선미 ${ }^{4}$

1동서대학교 보건의료계열 보건행정학과 교수, ${ }^{2}$ 고신대학교 의료경영학과 교수, ${ }^{3}$ 영산대학교 의료경영학과 교수, ${ }^{4}$ 국민건강보험공단 건강보험연구원 연구위원

목적: 국민건강보험 빅데이터를 사용하여 비만의 질병발생 및 사망 위험을 평가하고, 비만의 사회경제적 비용을 산출하는 것을 목적으 로 하였다.

방법: 2003-2004년에 일반건강검진을 받은 모든 수검자 중 체중 또는 키 측정값이 없는 사람, 중복수검자, 그리고 수검일 기준 과거 1년 간 비만관련 질병 과거력이 있는 자를 제외하였고, $10,091,251$ 명을 2015년 연도말까지 추적관찰한 코호트자료를 구축하였다. 이 코호트 에 건강보험 자격자료, 건강검진자료, 의료이용자료, 통계청 사망원인자료를 연계하여 분석하였다. 연령과 건강 행태를 보정한 후 성별과 비만 정도에 따라 질병발생 및 사망에 대한 상대위험도를 산출하였다. 인구기여위험도는 국민건강영양조사 원시자료의 비만율과 건강 검진 코호트 분석을 통한 질병 발생 및 사망위험도를 이용하여 산출하였다. 비만의 사회경제적인 비용은 의료비, 간병비, 교통비를 포함 하는 직접비와 조기사망에 따른 미래소득 손실액, 의료이용에 따른 생산성 손실액을 포함하는 간접비로 분류하여 산출하였다.

결과: 남성과 여성 모두 체질량지수가 증가함에 따라 당뇨병의 위험이 증가했다. 고도비만 남성의 당뇨병 위험은 정상 체중 남성의 4.83 배 높았다. 비만 여성의 당뇨병 위험은 정상 체중 여성보다 4.01 배 높았다. 비만의 사회 경제적 비용의 경우, 2015년의 남성과 여성의 비만 관련 직접비는 각각 $50.8 \%$ 와 $85.9 \%$ 로 직접비와 간접비에 성별 차이가 있었다.

결론: 비만은 질병발생과 사망의 중대한 위험 요인일 뿐 아니라 건강보험에서 경제적 손실 원인이기도 하다. 따라서, 향후 비만으로 판 정된 수검자를 관리하기 위한 중재프로그램을 개발하는 것이 필요할 것으로 사료된다.

주제어: 비만, 성, 사회경제적 비용, 질병, 사망 